New Zealand Journal of Employment Relations, 45(2): 42-56

\title{
Covid-19 and Employee Surveillance
}

\section{STEPHEN BLUMENFELD*, GORDON ANDERSON** and VAL HOOPER ${ }^{* * * *}$}

\begin{abstract}
While working from home is not a new concept, the advent of the Covid-19 pandemic has, for many in the workforce, rendered it the 'new normal', concomitant with enhanced use of workplace surveillance technologies to monitor and track staff working from home. Even prior to the global pandemic, organisations were increasingly using a variety of electronic surveillance methods to monitor their employees and the places where they work, whether it be in an office building or remotely. This technology traverses various facets of the work environment, including email communications, web browsing, the use of active badges for locating and tracking employees, and the gathering of personal information by employers. The application of these technologies, nevertheless, raises privacy concerns, which are exacerbated when work is undertaken in employees' own homes, a phenomenon that has become more prevalent due to Covid-19. This article addresses the issue of electronic workplace monitoring, its implications for employees' privacy and the role of collective bargaining in addressing this emergent practice, which has also been given new impetus during the pandemic.
\end{abstract}

Keywords: Covid-19, pandemic, employee surveillance, monitoring, performance, digital Taylorism, remote work, trade unions, collective bargaining, privacy

Anyone familiar with George Orwell's 1984 will relate to the menace of 'Big Brother' watching their every keystroke and mouse click. It seems, for a growing share of the workforce, that dystopian reality has arrived, and what might have been said to be little more than a management fad looks to have blossomed into a full-fledged trend, doing so while most of us hunkering down in our 'bubbles'. Toward that end, expansion of the phenomenon of working from home during the current Covid-19 pandemic (Radio New Zealand, 2020) has given new impetus to organisations tracking their employees, and there is now a full arsenal of surveillance technology enabling them to do so. According to a recent report of the Trade Unions Congress (2020), the largest federation of trade unions in England and Wales, 15 per cent of those workers it surveyed contend that monitoring and surveillance at work has increased during the Covid-19 pandemic.

Of course, the crusade for flexible work options began long before the Covid-19 pandemic and workingfrom-home is a not new concept in employment. Data from the 2018 Survey of Working Life, conducted between October and December 2018, suggest that just over half of employees in New Zealand had access to flexible working hours at that time. Despite this, only around a third had ever worked from home and

\footnotetext{
* Senior Lecturer, School of Management, Te Herenga Waka-Victoria University of Wellington, New Zealand

** Professor of Law, Faculty of Law, Te Herenga Waka-Victoria University of Wellington, New Zealand

*** Assoc. Prof, Head of School of Marketing and International Business, Te Herenga Waka-Victoria University of Wellington
} 
fewer than three per cent worked predominantly from home (Statistics New Zealand, 2019). As revealed in research undertaken between March and July 2020, though, the incidence of remote working in New Zealand increased from 20 to 43 per cent in the four months following identification of the country's first case of Covid-19 (Williams, 2020).

With an increasing proportion of the labour market shifting to working from home, so too were an increasing number of workers being subjected to intensive supervision by means of electronic monitoring (Reuschke \& Feldstead, 2020). US companies Hubstaff and Veriato, which develop and market employee time-tracking software, each boasted a three-fold increase in New Zealand sales of its worker surveillance software during the first month alone of the Covid-19 lockdown. Teramind, another US-based company, which produces a dashboard to compare workers based on their productivity, and EfficientLab, a Russianbased company that monitors computer activity and produces traffic and work time logs, reported a similar a three-fold growth in New Zealand between March and June (Hatton, 2020).

Related to this, jobs where monitoring and micro-management of workers are rife are among those most at risk of being replaced by automation (OECD, 2019). Yet, as Peetz (2019) has observed, "Technological change in itself is neither malevolent nor benign. What matters is the social context within which it exists and the use to which it is put" (p.100). Videlicet, while a great deal has been made of the prospect of technological job loss and robots 'stealing our jobs', the proliferation of algorithmic decision-making, the surveillance of employees and monitoring of workplaces, and regulatory arbitrage via the use of contingent or peripheral workforces - what Peetz (2019) calls 'not there' employment - pose a far greater threat to workers (see also Rogers, 2019).

\section{Historical and theoretical underpinnings}

Digital technologies lend themselves to employer control strategies (Jeske \& Santuzzi, 2015; Kidwell \& Sprague, 2009). The use of surveillance as a form of social control is central to the writings of Marx, Durkheim and Weber, and workplace surveillance, control over the labour process and worker resistance endure as salient themes in employment relations (Hodder, 2020). As mechanisms of control over the labour process, the introduction of new technologies, more generally, alters the power dynamic between labour and management, and heightens the myriad conflicts and tensions inherent to the structured antagonism of the employment relationship (Edwards, 1990).

In a similar vein, although digital technologies can facilitate collective organisation, their use is just as likely to foster a division of labour and fragmentation of the workforce and management's control over both internal and external communication flows. Consequently, much as surveillance of the public under an authoritarian regime can serve to suppress political dissent, so too can the use of technology designed to facilitate surveillance in the workplace impede efforts to organise workers (Peetz, 2019). There is, likewise, the risk that, through compiling a limitless dossier on each employee and utilising growing levels of policing and surveillance, employers will seek to demobilise their workforces (Fleming, 2015). 
Whereas the exploitation of technology for such purposes is nothing new, electronic monitoring of workplaces and workers themselves is an emergent phenomenon and represents more than a perfunctory punching of a time clock. The pre-industrial factory system established around the notion that the concentration of workers in cottage factories, for instance, was more amenable to monitoring and directing workforces than was homework (Landes, 2003). Within the modern workplace, though, surveillance of employees typically involves the use of video cameras or audio recording devices, and the last decade has witnessed an increasing trend toward use of more intrusive surveillance technologies in workplaces. Media reports from overseas suggest that some employers are even contemplating the implantation of identifying and recording devices within their employees' bodies (NZCTU, 2018).

The extensive monitoring of workers is also central to the Fordist/Taylorist production models, often considered to be of a bygone era as well (De Stefano, 2018). Nevertheless, while the introduction of new technology in the workplace can afford workers greater autonomy and control over their work, the enhanced use of digital technologies to standardise and monitor tasks gives rise to what is known as 'digital Taylorism', which has the opposite effect (Brown et al., 2010). Also, by adding further distractions not found in the confined workplace environment, thereby reducing time devoted to work without a commensurate reduction in workload, remote working can result in the intensification of work (Kelliher \& Anderson, 2009). In this sense, technology is harnessed to affect deskilling and the division of labour, and work is redesigned to accommodate demands for greater efficiency, with little or no concern for the impact that such tight control may have on intrinsic job quality (Gallie, 2013).

As the use of digital technologies at work becomes more prevalent, electronic monitoring is expected to become established as the norm across workplaces, as is the concomitant technostress associated with the introduction of those technologies (De' et al., 2020). Where workers' output is precisely measured and their work subject to tight control and monitoring, as in call centres (Bain \& Taylor, 2000; Bain et al., 2002; Ellis \& Taylor, 2006, Ball \& Margulis, 2011) or online retail (Briken \& Taylor, 2018; Moore \& Newsome, 2019), the characterisation of the workplace as essentially Taylorist and the labour process as monotonous, intensive and frequently stressful seems all the more appropriate during the Covid-19 pandemic. That is, the tight control and monitoring of work, where it is feasible for that work to be undertaken at home, is likely to have been exacerbated in the current context, in which many employers have reluctantly acquiesced to accepting such work arrangements, more or less out of necessity (Hodder, 2020).

\section{Employee monitoring and performance}

There remains a perception that time spent on a job equates to higher quality work, but this is not necessarily correct. For example, in the IT, manufacturing and service sectors, the focus is very much on the task, with employees often dotted all over the world contributing their input across different time zones with the employee choosing when to complete the required task. On the other hand, it could be argued that monitoring employees' performance of time-dependent tasks leads to greater efficiency. It is 
important to monitor time-dependent tasks so that shift workers, in particular, are able to take over their shift at precisely the right time. Monitoring is also a means of ensuring the security and safety of staff, chiefly those working on night shifts. Similarly, the presence of sales assistants on shop floors at scheduled times can be monitored to ensure optimal service coverage. Finally, a record of the time taken for travelling salespeople or delivery staff to reach different destinations can provide insight into logistic efficiencies.

Notwithstanding the potential positive effects on efficiency, employee surveillance and workplace monitoring are more often used to monitor attendance, work effort and proof of hours worked - in other words, to check up on workers and intimidate them to be more productive (Australian Council of Trade Unions, 2019). This is perhaps even more appropriate when applied to working from home. The irony in the expanded use of such tools as a means of enhancing productivity is that, as much research has shown, an organisational culture of mistrust impacts negatively on employee productivity. To wit, surveillance and electronic monitoring of workers and the workplace can undermine the employer's productivity objective in implementing such measures (Van Gramberg et al., 2014; Henderson et al., 2018; Peetz, 2019).

\section{Employee responses to surveillance}

Recent scholarship on the relationship between technology and work has focused prominently on the psychological effects of workplace surveillance and electronic performance monitoring. These include an increase in stress and a drop in morale, ultimately resulting in the workers being concerned of devoting less time to their jobs. The Australian Council of Trade Unions (2019), for instance, has cited digital tracking and other unreasonable surveillance as a source of continuous performance pressures imposed upon gig workers, whether independent contractors or employees, in sham contracting arrangements. As applies to all workers more generally, one of the challenges posed by the use of video surveillance and electronic technology for that purpose is that such mediated forms of monitoring and micro-management restrict worker autonomy and amplify job strain, both catalysts of higher absenteeism and turnover (Weil, 2014; OECD, 2014).

The empirical literature also points to alienation and resistance as common responses to the use of workplace surveillance in its various forms (Edwards, 2000). Conversely, as one study of employees' reactions to technologies used to monitor their job-related activities has found, affording affected workers input into the process heightens their feelings of procedural justice and reduces the intensity of employees' perceptions of invasion of privacy (Bradley, 2001). Also illuminating in this regard is New Zealand's Inland Revenue Department's experience in the aftermath of the Christchurch earthquakes, during which staff working unmonitored from home out of necessity showed to be both resilient and trustworthy, demonstrating resourcefulness when faced with difficulties gaining access to networks (Donnelly \& Proctor-Thomson, 2015). This suggests that sufficient openness and trust for honest, frank, and supportive discussions between employer and employee are needed in order to counter the potential negative effects of workplace surveillance on efficiency and productivity. 
New Zealand Journal of Employment Relations, 45(2): 42-56

\section{Surveillance and the erosion of trust}

Working from home or other remote locations requires trust between employer and employee. Employers' characteristic reluctance to support, let alone encourage, working from home stems from a concern for lower productivity, loss of intellectual property, theft of valuable information assets and enhanced potential for employees to abuse email and the internet. In particular, the increasing use of electronic monitoring and surveillance technology points to a fundamental distrust that employees will shirk or drift if not continually monitored, should they move outside of the traditional workplace (Staples, 2014). This may offer a plausible explanation for why working from home and other modes of telecommuting failed to gain broader acceptance prior to Covid-19. However, it also indicates that employers may have little understanding of the empirical connection between trust in the employment relationship and labour productivity.

One implication of the deterioration of trust in the employment relationship, precipitated by development and use of electronic surveillance and performance monitoring in the workplace and a shift to working from home, is the potential for these dual phenomena to further erode and diminish the significance of what Kochan (2004) and Lansbury (2004) have referred to as the 'social contract at work'. Deriving from Rawlsian political philosophy, as applied to the employment relationship, social contract theory posits that both parties have agreed, either explicitly or tacitly, to contribute to the wellbeing of the organisation as a whole and that, in so doing, have also agreed to give something up - a quid pro quo, if you will - in return for the collective benefit derived from their relationship.

Others have cloaked this dilemma in the context of the 'psychological contract' in employment, to which trust is also fundamental (Rousseau, 1989; Guest, 2016) and the satisfaction of which is key to achievement of the objectives of human resource management (e.g. Robinson et al., 1994; Guest \& Conway, 1999), including employee retention (Cotton \& Tuttle, 1986). Paradoxically, because their use is likely to undermine the trust between workers and employers and negatively impact the quality of work, electronic surveillance in the workplace - be it on the shop floor, office or workers' homes - is unlikely to induce workers to work harder or produce more (Henderson et al., 2018). Yet, notwithstanding overwhelming evidence that such low-trust practices can be counter-productive and engender animosity and contempt towards management, digital technologies are increasingly exploited as a means of brandishing control over employees (Van Gramberg et al., 2014).

\section{Privacy considerations}

In addition to leading to employees feeling mistrusted, use of electronic surveillance and monitoring software to track employee activity and productivity is often seen as an intrusion upon their privacy, a concern writ large when employees are working remotely and especially when they are working from home. In some circumstances, such to ascertain whether an employee is abusing sick leave or is engaging 
in 'undesirable' conduct, surveillance by employers may also take place outside of work, including that which involves observation of an employee in their own home. Privacy issues obviously arise in such circumstances, and markedly so when the surveillance is carried out without the employee's knowledge and outside of their working hours. Despite those concerns, there are few restrictions in New Zealand law on workplace surveillance (Britton, 2006).

Taken at face value, the monitoring and surveillance of workers would appear to risk breaching New Zealand's privacy laws. The principles of the Privacy Act 1993, for instance, require that employees be informed of any information being collected about them and the purpose for which the information is being collected, how it will be used, how it will be stored, who will have access to it, whether it will be able to be modified and by whom, and to whom such information may be disclosed. The information should also not be kept for longer than necessary, and it is essential to know how it will eventually be disposed of and by whom. These requirements extend to any surveillance technology or monitoring software the employer installs on work computers, particularly if they are permitted to be used for personal use or at home.

Pursuant to s.66 of the Privacy Act, any party who is subject to a breach of their informational privacy may lodge a complaint with the Privacy Commissioner alleging an interference with their privacy. In spite of this, the Act generally does not apply to the monitoring of employee email and internet services by employers and, while informational privacy is protected under the Act, there is no civil liability for a breach of informational privacy (Britton, 2006). Moreover, in cases considered by the Privacy Commissioner, surreptitious video or audio recording of workers by employers has largely been deemed permissible under the Privacy Act. This results from exceptions in the legislation arising from the Commissioner's duty to balance workers' privacy interests against the legitimate interest of the employer in running their business efficiently (Roth, 2016). For these reasons, the recently enacted Privacy Act 2020, in which that duty remains intact, is unlikely to alter the status quo, which has largely favoured managerial prerogative over the privacy rights of workers.

\section{The role of employment law}

For the most part, then, any protections New Zealand workers may have against the otherwise unfettered surveillance activity of their employers derive either from the country's employment law or from collective bargaining. But, like the Privacy Act 1993, the Employment Relations Act 2000 only requires that any collection of personal information be reasonably necessary and undertaken in a fair and reasonable manner. This implies that any action of the employer based on information obtained through monitoring or surveillance that might be construed as harmful to the employee must be substantively and procedurally justified. Neither statute, however, offers any guidance as to "what a fair and reasonable employer could have done in all the circumstances" (Roth, 2016). 
One conclusion which might be drawn from this is that, if those working from home are to have any protection against the unmitigated intrusion of their employers into their personal lives, a more robust approach to good faith will be required. Such an approach, including acceptance by the courts that good faith extends to an employee being entitled to protect their private life, should arguably require the bar that employers must reach in order to justify intrusion into an employee's home be raised well above where it currently stands. At a minimum, one might expect that all reasonable alternatives for assessing an employee's work effort and performance be shown to be unsuitable and that mitigating the potential for psych-social harm resulting from such intrusion be construed as necessary requirement of good faith (Anderson, forthcoming). In any event, the status quo is that employees have very limited protection under New Zealand's employment law against employer surveillance, irrespective of whether they are working from home or in the workplace.

\section{Trade unions and collective bargaining}

In spite of - or perhaps because of - the lack of protection afforded to workers under New Zealand law, the use of technology, not only in directing but also in monitoring their work, and the implications of that use for those workers' health and wellbeing and privacy rights have become subjects of collective bargaining. More generally, provisions in collective agreements pertaining to the use of surveillance technology in the workplace typically regulate how and under what circumstances employers can collect information on employees and how and for what purposes that information may be used. These clauses often impose constraints on the ability of employers to impose sanctions or dismiss employees based on information obtained through the monitoring of workplaces using electronic surveillance tools (Henderson et al., 2018).

Trade unions are acutely aware that monitoring and surveillance tools, often introduced outside of the collective bargaining process, impact workers' privacy and can be unfairly used for performance-related purposes. Elsewhere in the world, unions are engaging with employers in 'algorithm negotiations', the aim of which being to restrict the use of 'people analytics' in evaluating work performance and to make hiring and firing decisions (De Stefano, 2018; Moore et al., 2018). Yet, there is little evidence that such usage of data obtained through surveillance of employees and the monitoring of workplaces has been the subject of collective bargaining in this country.

The risk of intimidation and surveillance as a factor limiting freedom of association protections and hindering access by workers subjected to such measures is also of concern to unions (Australian Council of Trade Unions, 2019). Notwithstanding such apprehensions, prior to the outbreak of Covid-19, relatively few New Zealand collective agreements - and one would assume even fewer individual employment agreements - included provisions in dealing with the use of technology to monitor employees' behaviour during working hours. Some employers' policies, though, permit the use of such technology. Furthermore, the industries in which provisions pertaining to work being electronically monitored exist are, for the most part, not those in which working from home is feasible. 
As can be seen in Figure 1, the share of collective agreements currently in effect in New Zealand that include some mention of workplace surveillance or work itself being electronically monitored varies considerably across the labour market. Among all collective agreements, only five per cent either include a specific clause or refer to a document outside of the agreement dealing with internet or telephone monitoring of employees. This pertains to nearly a quarter of collective agreements in the retail sector. On the other hand, no collectives negotiated in accommodation and food services include such a clause or reference.

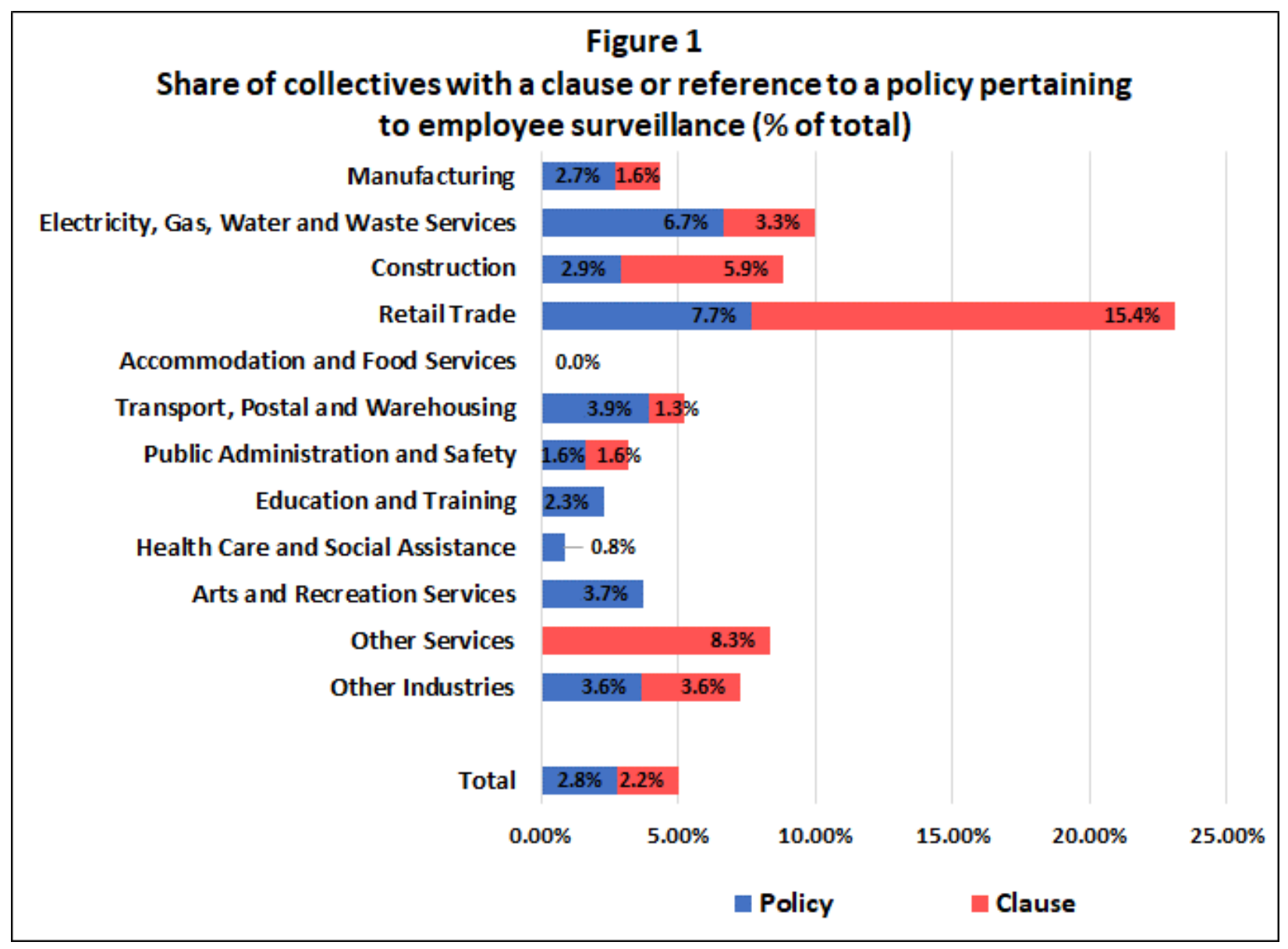

Importantly, there are undoubtedly far more collective agreements that make no mention of this type of surveillance, but which cover work that is regularly surveilled or monitored by the employer. In a number of those cases, the employer may rely on a separate policy document related to employee surveillance which is not identified in a collective agreement. Also relevant is that these data exclude the approximately 80 per cent of jobs which are covered by an individual employment agreement, many of which could well be subject to surveillance by the employer. Of particular significance in this regard is that neither retail nor the hospitality sector has a high level of collective bargaining coverage, meaning that most jobs in these sectors are covered by individual employment agreements, thus leaving the conditions of employment and any decision on whether the work involved will be monitored subject to the whim of the employer. 
The picture, in fact, looks quite different when we consider the relative coverage of collective agreements that include reference to employee surveillance, as shown in Figure 2. Four industry groups manufacturing, construction, retail trade and health and social assistance - encompass more than twothirds of all employees on collective agreements that include provisions dealing with these issues. To that end, more than 20 per cent of employees on collective agreements in both manufacturing and retail trade and around one in six in health and social assistance are covered by such a clause.

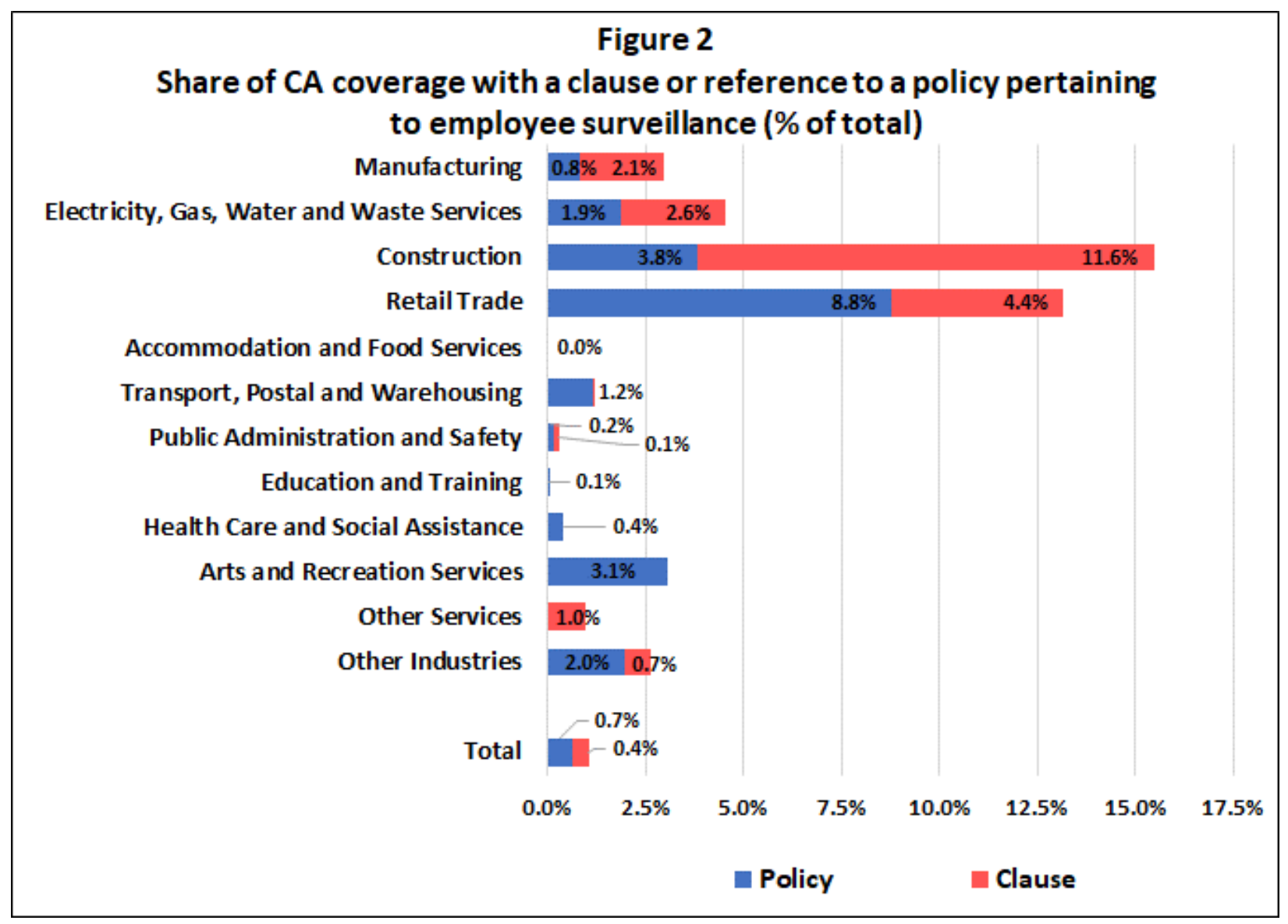

Only one in 10 employees on collective agreements in public utilities, in which coverage is currently around 18 per cent, are on an agreement with a provision related to electronic monitoring of work. This leaves approximately 2600 out of a total of around 2900 employees working in the electricity, gas, water and waste services industries on a collective that includes no mention of surveillance or monitoring of their work. Nonetheless, many of those workers will frequently work remotely, outside of the formal office, and the services provided by the organisations for which they work are themselves typically subject to extensive monitoring and regulation, as is the work performed by employees of public utilities.

While the data here confirm that, at 13.2 per cent, it is relatively common for an employee who is among the approximately five per cent of all employees in retail trade on a collective agreement to be covered by such a provision. Moreover, an even larger share of those on collective agreements in construction have either a clause (11.6 per cent) or a reference (3.8 per cent) to employee surveillance in their 
New Zealand Journal of Employment Relations, 45(2): 42-56

agreement. Despite this, most employees on collectives, regardless of where they are situated in the labour market, are unlikely to have any provision related to employee surveillance in their agreement. This could change, though, what with more and more people working remotely, away from the traditional workplace.

\section{Conclusion}

Uncertainty around when the global pandemic will end has moved many employers and employees to think of working from home as the 'new normal' (Bonacini et al., 2020). At the same time, there is cause for concern that employers will seek to extend their control over the labour process by intruding into their employees' homes and their lives off the clock. What's more, with jobs in scarce supply - at least for the time being - and their bargaining power commensurately limited, workers are likely to be disinclined to object to digital surveillance software being installed on their personal or home computer (Lazar, 2018). Apart from the opportunity created by Covid-19 or perhaps the feeling of entitlement, however, are there other reasons employers may choose to monitor their employees' activities when working away from the office, including at home?

The unitarist ideals of the primacy of management prerogative and the duty of fidelity on the part of the employee have been increasingly used to justify the ever more invasive intrusion into their employees' private lives. Two manifestations of this are the increased monitoring of employees' use of social media platforms and the progressively more invasive surveillance of employees both inside and outside the workplace, especially within their own homes. Additionally, as this article illustrates, there is mounting evidence that the latter has received considerable impetus from Covid-19, with some employers giving in to the temptation to closely monitor their employees while working at home during the pandemic. Although employers were using surveillance technology to monitor their workplaces and employees well before the pandemic, to the extent to which working from home becomes the 'new normal', electronic monitoring threatens to remain in vogue long after the health threat posed by the pandemic has subsided.

Concern expressed by workers and their representatives over the introduction of surveillance tools in the workplace - be it in an office, at home or other remote location - is with its potential for social disruption, its impact on workers' privacy, and its capacity for use in managing performance (European Trade Union Confederation, 2020; Trades Union Congress, 2020; NZ Productivity Commission, 2019). Yet, while unions have articulated their apprehension over the growing pattern of use of new technologies for this purpose, it is still rare for monitoring and surveillance to be considered in collective bargaining. The relative dearth of collective agreements that include provisions pertaining to worker surveillance may reflect the fact that employers commonly introduce the use of surveillance technology outside of the collective bargaining process. It may also be that workplace surveillance is not something unions have heretofore chosen to prioritise in collective bargaining.

Whereas it is arguable that more could be done in collective bargaining to address this issue, in light of diminishing collective agreement coverage, most notably in the private sector, there may be a need for legal restrictions to be placed on the use of electronic surveillance technologies as a means of monitoring employee performance. As noted by Henderson et al., (2018), "The problem is not the technology itself, ...but rather the power relations and regulatory environments within which they are used and 
implemented" (p.20). To that effect, even where union density or collective bargaining coverage are low, in many countries, employers are restricted by privacy laws from conducting certain types of electronic surveillance on their employees, including intercepting and accessing electronic communications (Riedy \& Wen, 2010). Nevertheless, notwithstanding the greater protections for individuals' personal information and new obligations for businesses and organisations promulgated by the government under the Privacy Act 2020, this also does not currently apply to New Zealand.

While the right to privacy and a private life are increasingly acknowledged, whether New Zealand's courts will come to insist that monitoring remote working, particularly in one's home, can be strictly limited and the necessity clearly demonstrated is, as of yet, unclear. One suspects, though, that employer arguments that employees have impliedly consented to what would, in any other context, be construed as an invasion of privacy and that such intrusion is necessary to prevent employees from shirking are unlikely to be successful challenged (Anderson, 2020). In conjunction with the dearth of clauses pertaining to employer surveillance and monitoring of workplaces in employment agreements, this judicial status quo implies that there are few, if any, constraints placed on Big Brother's ability to keep the citizens of Oceania perpetually under surveillance! The current health crisis precipitated by Covid-19 merely underscores this existing state of affairs.

\section{References}

Anderson, G. (forthcoming), Realising Parliament's Vision for Good Faith. Employment Law Bulletin.

Australian Council of Trade Unions. (2019). Fixing the On-demand Economy and Other Insecure Work. Submission to the Inquiry into the Victorian On-demand Workforce (ACTU Document No. 6/2019). $\quad$ https://s3.ap-southeast-2.amazonaws.com/hdp.au.prod.app.vicengage.files/3915/5669/1083/Australian_Council_of_Trade_Unions.pdf

Bain, P., \& Taylor, P. (2000). Entrapped by the 'Electronic Panopticon'? Worker Resistance in the Call Centre. New Technology, Work and Employment, 15(1), 2-18.

Bain, P., Watson, A., Mulvey, G., Taylor, P., \& Gall, G. (2002), Taylorism, Targets and the Pursuit of Quantity and Quality by Call Centre Management. New Technology, Work and Employment, 17(3), 170-185.

Ball, K., \& Margulis, S. (2011). Electronic Monitoring and Surveillance in Call Centres: A Framework for Investigation. New Technology, Work and Employment, 26(2), 113-126.

Bonacini, L., Gallo, G., \& Scicchitano, S. (2020). Working from Home and Income Inequality: Risks of a 'New Normal' with COVID-19. Journal of Population Economics, 33(4), 1-58.

Bradley, A. (2001). Effects of Computer Surveillance on Perceptions of Privacy and Procedural Justice. Journal of Applied Psychology, 86, 797-804. 
Briken, K., \& Taylor, P. (2018). Fulfilling the 'British Way': Beyond Constrained Choice - Amazon Workers' Lived Experiences of Workfare. Industrial Relations Journal, 49(5-6), 438-458.

Britton., R. (2006). An employer's right to pry: a study of workplace privacy in New Zealand. 12 Canterbury Law Review 65.

Brown, P., Lauder, H., \& Ashton, D. (2010). The Global Auction: The Broken Promises of Education, Jobs, and Incomes. Oxford University Press.

Cotton, J. L., \& Tuttle, J. M. (1986). Employee turnover: A meta-analysis and review with implications for research. Academy of Management Review, 11(1), 55-70.

De Stefano, V. (2018). "Negotiating the algorithm": Automation, artificial intelligence and labour protection (Employment Working Paper No. 246). https://www.ilo.org/wcmsp5/groups/public/--ed_emp/---emp_policy/documents/publication/wcms_634157.pdf

De', R., Pandey, N., \& Pal, A. (2020). Impact of digital surge during COVID-19 pandemic: A viewpoint on research and practice. International Journal of Information Management, 55(December). https://doi.org/10.1016/j.ijinfomgt.2020.102171

Donnelly, N., \& Proctor-Thomson, S. B. (2015). Disrupted work: home-based teleworking (HbTW) in the aftermath of a natural disaster. New Technology, Work and Employment, 30(1), 47-61. https://doi.org/10.1111/ntwe.12040

Edwards, P. (1990). Understanding conflict in the labour process: The logic and autonomy of struggle. In D. Knights \& H. Willmott (Eds.), Labour Process Theory. London: MacMillan (pp.125-152). Macmillan

Edwards, P. (2000). Discipline: Towards Trust and Self-Discipline. In S. Bach \& K. Sisson (Eds.), Personnel Management: A Comprehensive Guide to Theory and Practice ( $3^{\text {rd }}$ ed.) pp.317-339. Oxford

Ellis, V., \& Taylor, P. (2006). You Don’t Know What You've Got Till It's Gone: Recontextualising the Origins, Development and Impact of the Call Centre. New Technology, Work and Employment, 21(2), 107-122.

European Trade Union Confederation. (2020, September 30). New Technologies Allowing More Surveillance at Work, ETUC Briefing Note: COVID-19 Watch. https://www.etuc.org/sites/default/files/publication/file/2020-10/20200930_covid19\%20Briefing\%20on\%20survelliance\%20technologies\%20\%28002\%29.pdf

Fleming, P. (2015). The Mythology of Work: How Capitalism Persists Despite Itself. Pluto Press.

Gallie, D. (2013). Skills, Job Control and the Quality of Work: The Evidence from Britain (Geary Lecture 2012). The Economic and Social Review, 43(3, Autumn), 325-341. 
Guest, D. (2016). Trust and the role of the psychological contract in contemporary employment relations. In P. Elgoibar, L. Munduate, \& M. Euwema (Eds.). Building trust and constructive conflict management in organizations (pp. 137-149). Springer International Publishing.

Guest D., \& Conway, N. (1999). Peering into the Black Hole: The Downside of the New Employment Relations in the UK. British Journal of Industrial Relations, 37(3), 367-389.

Hatton, E. (2020, June 2). Employee surveillance software sales surge in lockdown. Radio New Zealand. https://www.rnz.co.nz/news/national/418055/employee-surveillance-software-sales-surge-inlockdown

Henderson, T., Swann, T., \& Stanford, J. (2018). Under the Employer's Eye: Electronic Monitoring and Surveillance Australian Workplaces. https://www.tai.org.au/sites/default/files/GHOTD\%202018\%20Under\%20the\%20Employer\%27. s\%20Eye.pdf

Hodder, A (2020). New Technology, Work and Employment in the era of COVID-19 - Reflecting on legacies of research. New Technology, Work and Employment (forthcoming). https://doi.org/10.1111/ntwe.12173

Jeske, D., \& Santuzzi, A. (2015). Monitoring What and How: Psychological Implications of Electronic Performance Monitoring. New Technology, Work and Employment, 30(1), 62-78.

Kelliher, C., \& Anderson, D. (2009). Doing more with less? Flexible working practices and the intensification of work. Human Relations, 63-106. https://doi.org/10.1177/0018726709349199

Kidwell, R., Sprague, R. (2009). Electronic Surveillance in the Global Workplace: Laws, Ethics, Research and Practice. New Technology, Work and Employment, 24(2), 194-208.

Kochan, T. (2004). Restoring Trust in the Human Resource Management Profession. Asia Pacific Journal of Human Resources, 42, 132-146.

Landes, D (2003). The Unbound Prometheus: technological change and industrial development in Western Europe from 1750 to the present $\left(2^{\text {nd }}\right.$ ed). Cambridge University Press.

Lansbury, R.D. (2004). Work, People and Globalisation: Towards a New Social Contract for Australia. Journal of Industrial Relations, 46(1), 102-115.

Lazar, O (2018). Work, Domination, and Contemporary Republicanism [Unpublished PhD Thesis]. University of Oxford.

Moore, P., Upchurch M., \& Whittaker, X. (2018). Humans and Machines at Work: Monitoring, Surveillance and Automation in Contemporary Capitalism. Palgrave Macmillan. 
Moore, S., \& Newsome, K. (2019). Management by Exception? The Taylor Review and Workforce Management. New Technology, Work and Employment, 34(2), 95-99.

NZ Productivity Commission. (2019). New Zealand, technology and productivity. Technological change and the future of work (Draft report 1). https://www.productivity.govt.nz/assets/Documents/740ce1e715/Draft-report-1_NZ-technologyand-productivity-v3.pdf

NZCTU (New Zealand Council of Trade Unions). (2018). Submission of the New Zealand Council of Trade Unions Te Kauae Kaimahi, New Zealand Public Service Association Te Pūkenga Here Tikanga Mahi (PSA), E tū and the New Zealand Nurses Organisation to the Justice Committee on the Privacy Bill 2018. https://www.union.org.nz/wp-content/uploads/2018/08/Privacy-Bill.pdf

OECD (2014). OECD Employment Outlook 2014. OECD Publishing, Paris. http://dx.doi.org/10.1787/empl_outlook-2014-en

OECD. (2019). OECD Employment Outlook 2019: The Future of Work. OECD Publishing, Paris. https://doi.org/10.1787/9ee00155-en

Peetz, D (2019). The Realities and Futures of Work, Canberra: ANU Press.

Radio New Zealand (2020, October 6). Employers willing to offer staff option of working from home. https://www.rnz.co.nz/news/business/427675/employers-willing-to-offer-staff-option-ofworking-from-home

Reuschke., D. \& Felstead, A. (2020). Changing workplace geographies in the COVID-19 crisis. Dialogues in Human Geography, 10(2), 208-212.

Riedy, M., \& Wen, J. (2010). Electronic surveillance of Internet access in the American workplace: implications for management. Information \& Communications Technology Law, 19(1), 87-99. https://doi.org/10.1080/13600831003726374

Robinson, S. L., Kraatz, M. S., \& Rousseau, D. M. (1994). Changing obligations and the psychological contract: A longitudinal study. Academy of Management Journal, 37(1), 137-152. https://doi.org/10.2307/256773

Rogers, B. (2019). Beyond Automation: The Law \& Political Economy of Workplace Technological Change. doi.org/10.2139/ssrn.332760

Roth, P. (2016). Privacy law reform in New Zealand: Will it touch the workplace? New Zealand Journal of Employment Relations, 41(2), 2016: 36-57.

Rousseau, D. (1989). Psychological and Implied Contracts in Organisations. Employee Responsibilities and Rights Journal, 2(2), 121-139. 
Staples, W. G. (2014). Everyday Surveillance: Vigilance And Visibility In Postmodern Life (2 $2^{\text {nd }}$ ed). Rowman \& Littlefield.

Statistics New Zealand (2019). Information Release: Survey of Working Life: December 2018 Quarter. https://www.stats.govt.nz/information-releases/labour-market-statistics-working-life-december$\underline{\text { 2018-quarter }}$

Trades Union Congress (2020, November 30). Technology managing people: The worker experience. https://www.tuc.org.uk/sites/default/files/202011/Technology_Managing_People_Report_2020_AW_Optimised.pdf

Van Gramberg, B., Teicher, J., and O’Rourke, A. (2014). Managing Electronic Communications: A New Challenge for Human Resource Managers. International Journal of Human Resource Management, 25(16) 2234-2252.

Weil, D. (2014). The Fissured Workplace: Why Work Became So Bad for So Many and What Can Be Done to Improve It. Harvard University Press.

Williams, S. (2020). Time Kiwis spent remote working doubled during lockdown. IT Brief. https://itbrief.co.nz/story/time-kiwis-spent-remote-working-doubled-during-lockdown 